\title{
Developing Geographic Skills through Experiments: Implementing Experiments in Geography Classroom through GeoBoxes
}

\author{
Jan Christoph SCHUBERT ${ }^{1}$ \\ Friedrich-Alexander-Universität Erlangen-Nürnberg \\ GERMANY
}

1Prof. Dr.; Friedrich-Alexander-Universität Erlangen-Nürnberg, Faculty of Humanities, Social Sciences, and Theology, Department of Didactics, Chair for Geography Education, Erlangen-Nürnberg, GERMANY. Jan.christoph.schubert [at] fau.de. ORCID: 0000-0002-5877-1911

\begin{abstract}
Experiments are an important way of working in the geography classroom. They promote and require numerous geographic skills. At the same time, experiments are only used comparatively rarely in geography lessons in Germany. In order to increase the frequency of experiments in the classroom and to better exploit their potential, GeoBoxes have been developed. These can be borrowed by teachers and contain all materials and worksheets. In the article the steps of the development of the GeoBox are presented. In addition, the concept, which aims in particular at a cognitive activation of the students during experimentation, is presented. Accompanying research provides first indications that the GeoBox seems to be suitable to arouse especially the situational interest of the students.
\end{abstract}

\section{Keywords}

Geographic Skills; Geography Education Research; Curriculum Material; Design Based Research; Students' Interests

To cite this article: Schubert, J. C. (2021). Developing geographic skills through experiments: Implementing experiments in geography classroom through GeoBoxes. Review of International Geographical Education (RIGEO), 11(2), 525-539. doi: 10.33403rigeo.851222 
Geography as a spatial human-environment discipline (German Geographical Society, 2014) draws on a variety of methods and ways of working methods. These geographic working methods can be assigned either to the social sciences or to the natural sciences (Mattissek, Pfaffenbach, \& Reuber, 2013; Pfeffer, 2006). Consequently, there are a number of different geographical skills that should be developed in geography classes. An important role is played by "gathering information / methods", which is defined in the "German Educational Standards in Geography" as "ability to collect and evaluate geographically/geoscientifically relevant information in real space and in media, as well as to describe the steps in the gathering of information in geography" (German Geographical Society, 2014, p. 9). Experiments are an important instrument for the gathering of geographic information (German Geographical Society, 2014; National Research Council, 2012); in the German curricula, experiments are mandatory as a geographical working method (Institut für Schulqualität und Bildungsforschung München, 2020; Otto, 2009).

Experiments serve (starting from a human-geographic question or problem) to identify cause-effect relationships in the physical geographical area (Roberts, 2010). Associated with this are a variety of geographic activities that can be paraphrased along the Scientific Discovery as Dual research (SDDS) model (Klahr \& Dunbar, 1988) as follows: In the preparatory phase, the formulation of adequate geographical questions and verifiable hypotheses is necessary. The students also have to plan the construction of an experiment (suitable for the question and hypotheses). During the implementation phase students have to build the experiment with the existing materials and have to handle measuring instruments and laboratory material appropriately. In addition, they must observe carefully and record their observations in a comprehensible way. In the follow-up phase, the students will refer back to the research question and the hypotheses, critically analyze the setup and the implementation, and finally contextualize the experiment with the human-geographic problem. This makes it clear that experimenting requires and promotes both practical geographic skills and cognitive ones. Experiments thus place high demands on both the teachers who prepare the lessons and the students (Akuma \& Callaghan, 2019). In sum, conducting experiments in geography lessons thus promotes a number of methodological, geographical skills and at the same time supports a deeper understanding of geographical content.

There is evidence, however, that teachers rarely use experiments in geography lessons, although students show a particularly high level of interest in experiments (Hemmer \& Hemmer, 2010). Reasons for this are organizational hurdles and the didactic-methodological qualification of teachers (Akuma \& Callaghan, 2019; Höhnle \& Schubert, 2016; Miener \& Köhler, 2013).

Against this background, we have developed a "GeoBox" on the topic of soil/agriculture (5th and 6th grade), which enables teachers to work on this topic with the help of experiments. The GeoBox contains all the materials, worksheets and teacher instructions required for the experiments. In this sense, the borrowable GeoBox is ready-to-use. The GeoBox should help to meet the high requirements for the use of experiments, so that experiments can be used more frequently and profitably. 
The paper aims to show the development of the GeoBox within a design-based research approach. In addition, the didactic concept of the GeoBox is presented. The central approach is the practical activation and the cognitive activation of the students - with the aim to promote the geographical skills of the students in the area of gathering information / methods. The concrete design of the GeoBox will be presented by means of an overview and concrete teaching materials. In addition, first research results on the evaluation of the GeoBox are presented, focusing on motivational characteristics of the students..

\section{Geobox: Developing Geographic Skills through Experiments in Geography Classroom}

\section{Iterative Development of the Geobox}

The GeoBox was developed within the framework of a design-based research (DBR) approach. DBR combines research and development work; learning settings developed on a theoretical basis can be tested and improved through research (Edelson, 2002; Wilhelm \& Hopf, 2014). In the present project, the focus is on the development and scientific examination of a didactic design, the GeoBox (DesignBased Research Collective, 2003). The starting point of DBR projects is usually a concrete challenge from practice (Wilhelm \& Hopf, 2014), in this case the need to integrate experiments into regular geography lessons. This is linked to the goals of, on the one hand, strengthening students' scientific literacy and, on the other hand, increasing students' motivation in geography classes. DBR projects follow several steps (Feulner, Ohl, \& Hörmann, 2015), which in the specific case are essentially as follows: (1) the design of the GeoBox, (2) the implementation of lessons with the GeoBox and an accompanying collection of research data, (3) the analysis of the collected research data especially with regard to conditions of success and effects of working with the GeoBoxes, and (4) a revision (re-design) of the GeoBox based on this analysis. Such a sequence is referred to in design-based research as a design cycle (Edelson, 2002; Design-Based Research Collective, 2003); for the development of the GeoBox, four cycles were followed, during which both the design of the GeoBox and the accompanying research evolved. The first designs of the GeoBox were created in the context of a university course with students as future geography teachers.

For this purpose, a parallel survey of university students was conducted, with the result that they would welcome (mean $=4.59, \mathrm{SD}=0.65)$ and use (mean $=4.13, \mathrm{SD}$ $=0.82)$ an offer of borrowable GeoBoxes $(\mathrm{N}=221$, five-point scale from $1=$ does not apply at all, $5=$ applies completely). In addition, it was asked how important certain aspects were rated for borrowable GeoBoxes (five-point scale with $1=$ very unimportant to 5 = very important). It was found that ready-to-use worksheets (mean $=4.19$ ), a curriculum reference for the topics covered (mean $=4.10)$, the fact that the offer is free of charge (mean $=4.08$ ), solution instructions for teachers ( mean $=4.06)$, technical background information for the teacher $($ mean $=4.02)$ and didactic instructions for the use of the experiments in geography lessons (mean = 4.01) were considered to be particularly important by the respondents. These criteria were taken into account for the design of the GeoBox. The first drafts of the GeoBox were discussed in the university seminar and optimized together. In the 
next step, the concept was presented to experienced geography teachers and further developed on the basis of the ideas contributed. Afterwards, the first application in class took place in two classes. Both the teachers and the students were interviewed by means of an open questionnaire, and there was also an oral exchange with the teachers. The teachers were asked to make an overall assessment and to name difficulties as well as suggestions for improvement. Among other things, the students were asked to complete two sentence starters ("I found the lessons with the GeoBox ... because ..." and "I would have wished that ..."). Overall, we received positive feedback from teachers and students even in the first run (including "The students were very active participants." // "The level of challenge for the students was appropriate." // "The help cards were a super aid, with them students were actually able to work independently and successfully."). At the same time, there was criticism (including "It was not always clear which material was needed in which lesson" // "The technical terms soil moisture and grain size were not introduced well enough.") as well as concrete suggestions for improvement. These included technical or organizational things (e.g., "The GeoBox should also contain cleaning supplies including a bottle brush.") but also didactic considerations ("Can you include a glossary in which basic terms are continuously entered?"). The results of the feedback were taken into account for the re-design. The adapted GeoBox went through a total of three such cycles with two classes each and was continuously optimized. A central element was a close exchange with the teachers at the same eye level. The third cycle was also used to pretest a quantitative instrument, which was then used for additional quantitative accompanying research in the fourth cycle.

\section{Contents and Materials of the GeoBox}

In terms of content, the GeoBox deals with the topic of "The importance of soil for agriculture", which is anchored in the curriculum of the $5^{\text {th }}$ grade in Germany. The aim of the GeoBox is to ensure that lessons are not taught classically with the textbook or through instruction by the teacher. Instead, the students are expected to work out the content themselves with as much individual activity as possible with the help of experiments; the teacher takes on an advisory and supportive role. The systematic inclusion of experiments strengthens the level of geographic skills: the students not only learn about the content of the topic of soil and agriculture, but also learn to a particularly high degree methodologically - they learn geographic ways of gaining knowledge, formulate research questions, create appropriate hypotheses, plan the design of experiments based on criteria, carry out experiments, evaluate experiments and reflect on the way of gaining knowledge.

The GeoBox is roughly divided into the following modules or lessons:

i. Spatial distribution of the cultivation of agricultural products in Germany and factors of production in agriculture (including soil)

ii. Discovering the properties of soils (as one of the factors of production for agriculture)

iii. Finding out the soil type (as an important soil property) through investigations - slurry analysis and finger test

iv. Experimentally investigate the influence of soil type on water holding capacity 
v. Experimentally investigate the effects of soil compaction (due to agricultural use) on the water holding capacity of soils

In the concrete design, care was taken to keep the preparation effort for the teaching staff as low as possible, which is why directly applicable worksheets were developed and compiled in a GeoBox together with all the materials required for the experiments in sufficient quantities. In this sense, the GeoBox is designed as a complete package. At the same time, however, individual adaptation to the needs of the class and the learning situation is possible. The lessons can also be implemented individually with slight modifications in the sense of a construction kit.

An accompanying folder was designed to facilitate and structure the implementation. This folder includes:

- Lesson plans (as a suggestion)

- $\quad$ Detailed lists of the materials required

- all worksheets including tasks

- Suggested solutions to the worksheets / tasks

As materials the GeoBox contains the following things (figure 1):

- Boxes with soil samples (sand, gravel)

- 14 magnifying glasses (for soil testing)

- 14 spray bottles (for water)

- 14 beakers $(250 \mathrm{ml})$

- 14 measuring cylinders $(250 \mathrm{ml})$

- 14 measuring cylinders $(100 \mathrm{ml})$

- 14 spatulas

- 14 funnels

- $\quad 2 \times 3$ soil sieves

- 7 trays (as bottom layers for experiments)

- Cleaning utensils (hand brush, shovel, cleaning cloth, brush)

- Small materials (aluminum foil, toothpicks, rubber bands, cloth wipes, absorbent cotton)

- 1 folder with materials and USB stick

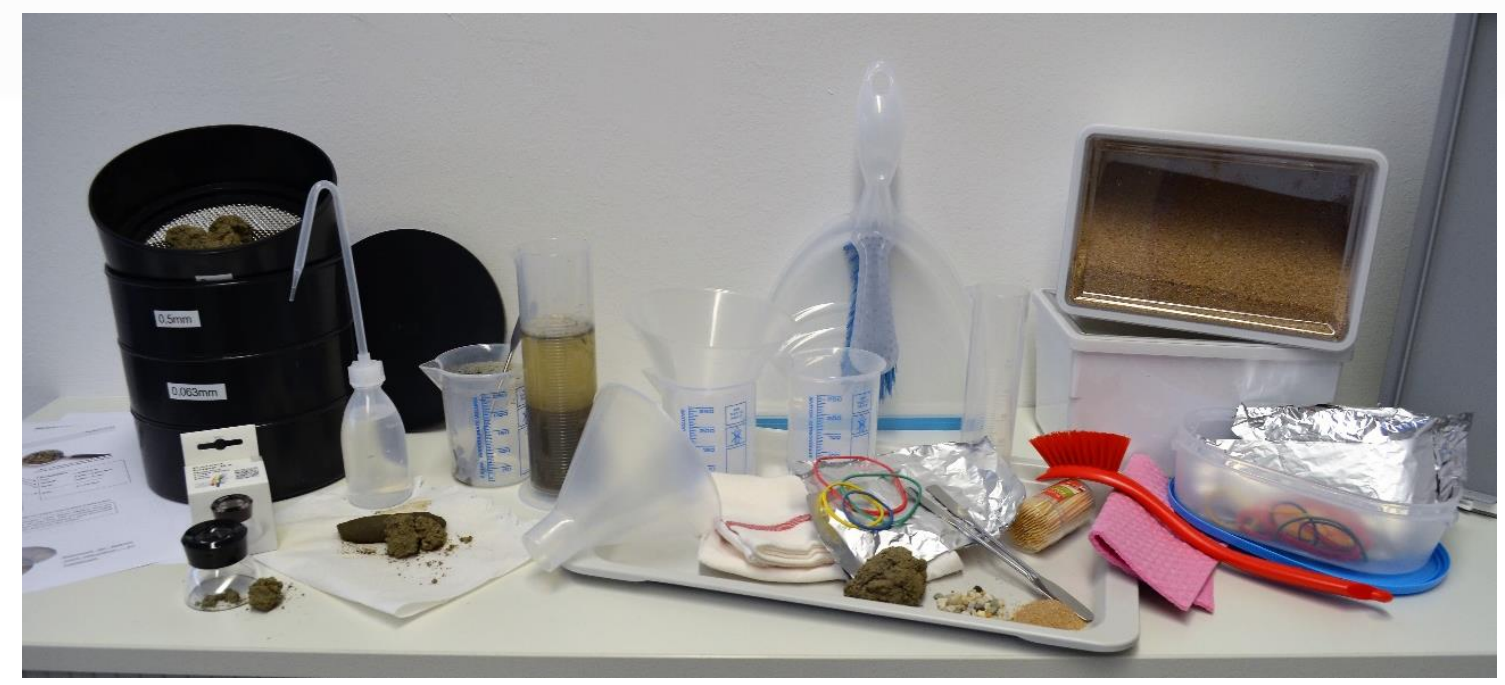

Figure 1. Contents of the GeoBox 


\section{Educational Concept of the Geobox: Hands-On and Minds-0n}

In the development of the GeoBox, basic principles of geography education were taken into account, such as lifeworld orientation, problem orientation, internal differentiation, graded support, pre-structured openness, constructive handling of errors, clarity, sensitive handling of technical language, and gender-sensitive learning materials.

Special attention was paid to the cognitive ('minds-on') and practical activation ('hands-on') of the students. Although the following explanations refer to experiments or the GeoBox, they are in many respects transferable to the acquisition of geographic skills. In scientific work, experimental abilities and skills in a more practical sense ('hands-on') are also necessary. These include, for example, knowledge of equipment and measuring instruments and adequate handling of these. Such basic knowledge is a prerequisite and a partial goal of science-oriented teaching. However, experimental work should not be limited to working through given experiment instructions (Hammann, Ganser, \& Haupt, 2007). Although such lessons can certainly train the handling of scientific equipment and be characterized by a high level of student activity, this primarily relates to the 'hands-on level'. In a video study on physics lessons, it was shown that the preparation and follow-up of experiment phases are of particular importance for the learning success of the students (Tesch \& Duit, 2004). This is because the content is embedded in these phases, as well as the planning of the procedure; a discussion and an evaluation of the results etc. take place. In these phases, therefore, the students are particularly active cognitively. Enabling the students to engage in this kind of 'minds-on' activity with the process of scientific knowledge is a central goal and at the same time a major challenge for the classroom (Hammann et al., 2007; Parchmann \& Prenzel, 2003). This can be promoted in different ways (Duit, Gropengießer, \& Stäudel, 2007; Hammann, Phan, Ehmer, \& Grimm, 2008; Schubert, 2016):

- Clear integration of the experiments into the teaching context (In the GeoBox there is a stringent reference to agriculture, at the same time the experiments are integrated into a researcher's story that runs through the entire GeoBox). 


\section{The water holding capacity of different soils}

Anna and Lukas continue to experiment with their soil samples. In the process, they have made an interesting observation. Kristin joins them again.

Kristin: What were you actually trying out earlier?

Anna: Just take a look at our experiment setup...

...And, do you now know what question we had in mind...?

a
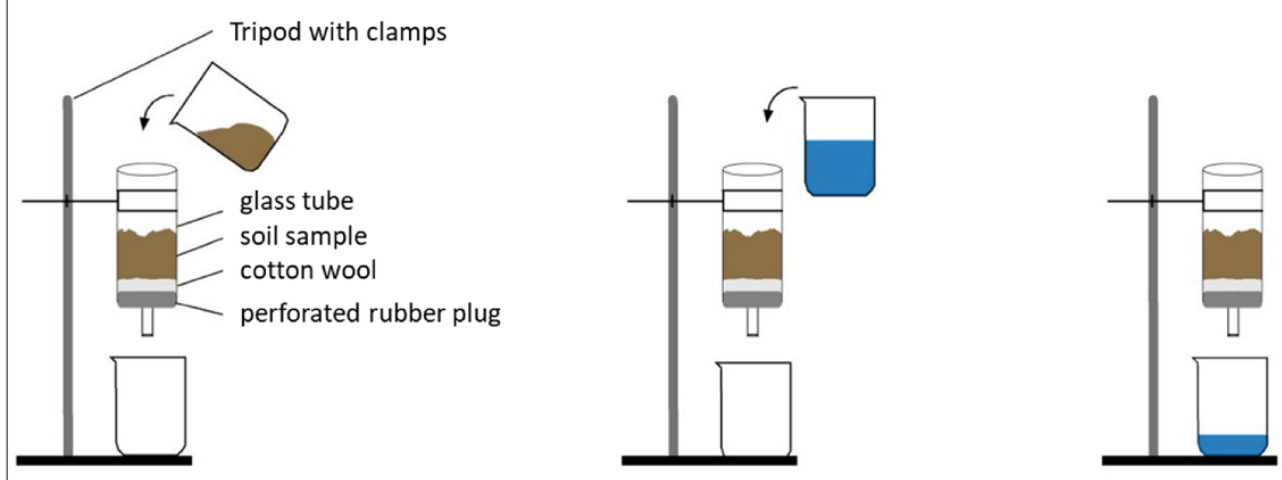

b
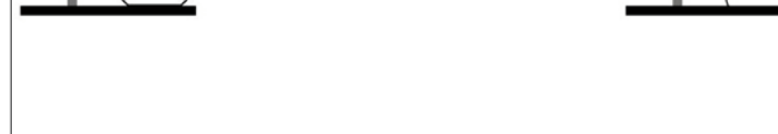

$15 \mathrm{~min}$ later

same amount of soil as in a)

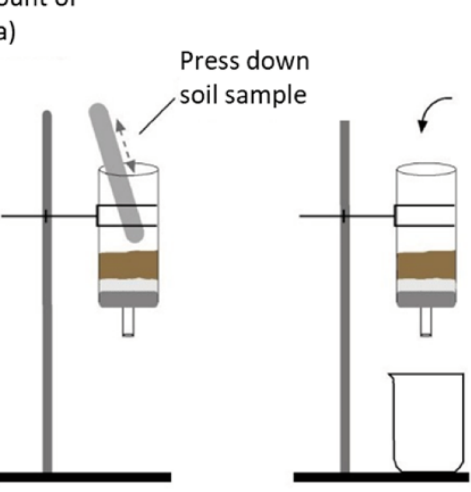

same amount of water as in a)
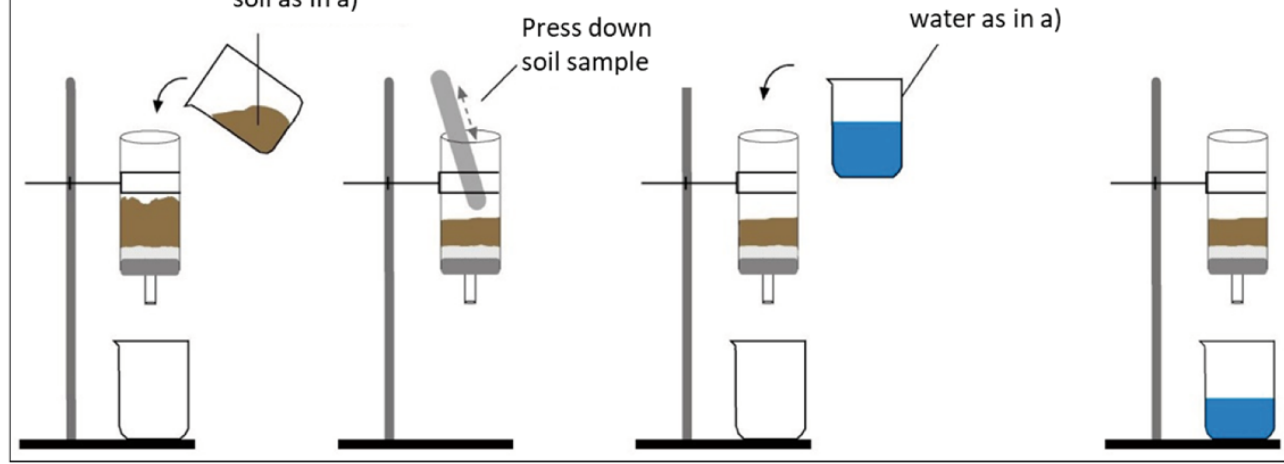

Tasks

1. Formulate a possible question and hypotheses that Anna and Lukas could have tested with this experiment setup!

Question:

Hypotheses:

2. Explain what conclusions can be drawn from the experiment.

Figure 2. Example of a worksheet for students from the GeoBox (translated) 
- Possibilities of independent planning, execution and evaluation of experiments by the students (In the GeoBox there is an increasing openness and an increasing independence of the students, which leads up to an independently planned experiment).

- Provision of more than the required materials in order to increase the cognitive challenge in planning experiments and at the same time to open up several possible solutions (In the GeoBox, the material box also contains things that are not needed or things that allow a different set-up (funnel and cloth instead of glass tube and absorbent cotton).

- Inclusion of work with predefined designs of experiments, which can be used to specifically diagnose and promote partial competencies of experimentation (In the GeoBox, for example, the students receive a drawing of an experiment setup. They are then asked to formulate appropriate hypotheses, figure 2).

- Integration of meta-reflective phases, in which the students discuss the characteristics, the significance, the limits etc. of experiments as a geographic working method (In the GeoBox such phases are integrated in small groups as well as in the plenum).

Ultimately, it becomes clear that not only the frequency of the use of geographic working methods such as experiments is decisive for the development of geographic skills, but also the way in which they are used in the classroom. Thus, the goal is not only the practical work ('hands-on') but also a thorough thinking through, a detailed processing and verbalization of assumptions, observations and interpretations in a common conversation (Möller, 2000).

\section{Geobox: Accompanying Research}

\section{Research Questions}

In the first cycles, qualitative feedback from teaching practice on the work with the GeoBox was collected. The focus of this accompanying research was on the improvement of the GeoBox. In the third cycle, a closed, item based questionnaire was additionally pretested, which was then used in the fourth cycle. This research of this fourth cycle will be briefly presented in the following.

It is known from numerous studies that students have a high interest in hands-on activities (Adey \& Biddulph, 2001; Bent, Bakx, \& Brok, 2014). In Germany, interest studies have shown that experiments are the most interesting way of working for students in geography classes (Hemmer \& Hemmer, 2010); however, at the same time, experiments are very rarely used (Hemmer \& Hemmer, 2010; Höhnle \& Schubert, 2016). A literature review also showed that student experiments do not per se lead to better performance and more satisfying development of interest, self-concept, and attitudes this is only the case if learning processes are strongly and sustainably supported (Duit \& Tesch, 2006). This raises the question of whether students find lessons with GeoBoxes that actually involve experimentation (involving hands-on and challenging minds-on activities) interesting.

The accompanying research focused on motivational effects of the GeoBoxes. In addition, students' perceptions of the hands-on and cognitive activities were recorded. 
These process features of instruction were also intended to validate the extent to which the GeoBox goal of including both hands-on and minds-on elements was achieved. Specifically, the following questions were explored: 1) How do student interests and selfrelated student characteristics differ between normal, previous geography instruction and geography instruction with GeoBoxes? 2) How do students perceive working with the GeoBox (compared to normal, previous geography classes) in terms of practical and cognitive activation?

\section{Methodology}

The accompanying research used a one-group pretest-posttest design. Scales from a study on physics education (PLUS study, Cronbach's alpha ranged from $\alpha=$ .67 to $\alpha=.86$; Kauertz et al., 2013) were used, slightly modified (essentially, only physics(instruction) had to be replaced by geography(instruction) in the items). The PLUS study also used a pretest-posttest design: Students first assessed previous, normal physics instruction ( $\mathrm{t} 1$ / pre) and then the lessons of the treatment ( $\mathrm{t} 2$ / post). A similar approach was used for the accompanying research on the GeoBox: the students were surveyed once immediately before the start of the treatment (= working with the GeoBox) about the lessons in the previous weeks (t1 / pre / normal lessons). The second survey with the same scales took place immediately after the end of the lessons with the GeoBox about the lessons with the GeoBox ( $\mathrm{t} 2$ / post / GeoBox). The questionnaire used contained modified scales from the PLUS study that captured interest, self-related student characteristics, and the process characteristics of instruction mentioned above. Students were asked to rate several items on a 4 -point Likert-type scale ( $1=$ not at all true to $4=$ true exactly). Data were entered into SPSS; analysis (following data cleaning) used descriptive and inferential statistical procedures. Due to the largely normal distribution of the data, paired-sample t-tests were used for the pre-post comparisons. In addition, when differences were significant $(\mathrm{p}<.05)$, the effect size $\mathrm{d}$ was calculated. The scales achieved satisfactory to good reliabilities according to Cronbach's alpha in this study (see tables 1, 2, and 3). The sample included two fifth grades (Gymnasium) in Bavaria (Germany) with a total of 43 students (25 of them female). The mean age was 11.04 years.

\section{Findings}

The students' interest was recorded in three scales: situational interest, topicspecific interest (this refers in particular to how much the students engaged with the topics beyond the classroom, i.e., reported on them at home, for example), and interest in geography (see table 1). The latter can be characterized as a more enduring, person-related characteristic. In contrast, situational interest in particular is related to the teaching situation, i.e. it allows conclusions to be drawn about perceived characteristics of the learning environment.

It can be seen that the students show a slightly positive situational interest in the normal geography lessons. A paired-samples t-test shows significantly more positive situational interest for working with the GeoBoxes than for previous, normal instruction; the effect can be classified as large.

In contrast, there are no differences in interest in geography and topic-specific interest between normal geography lessons and working with the GeoBox. Thus, 
students do not have a greater general interest in geography after GeoBox lessons. Furthermore, they did not exchange or inform themselves more about the topics of soil/agriculture after the lesson than they did with the previous lesson topics.

Table 1

Student Interest in Previous Lessons Compared To Lessons with the Geobox, N = 43

\begin{tabular}{|l|l|l|l|l|l|l|l|}
\hline & mean $_{\text {pre }}$ & $\boldsymbol{S D}_{\text {pre }}$ & mean $_{\text {post }}$ & $\boldsymbol{S D}_{\text {post }}$ & $\boldsymbol{t}(42)$ & $\boldsymbol{p}$ & $\boldsymbol{d}$ \\
\hline $\begin{array}{l}\text { situational interest } \\
\text { 6 Items } \mid \alpha=.87\end{array}$ & 2.58 & 0.64 & 3.18 & 0.66 & 6.03 & $<.001$ & 0.92 \\
\hline $\begin{array}{l}\text { topic-specific } \\
\text { interest } \\
\text { (leisure activities) } \\
\text { 6 Items | } \alpha=.73\end{array}$ & 2.10 & 0.54 & 2.03 & 0.52 & 1.19 & n.s. & \\
\hline $\begin{array}{l}\text { interest in } \\
\text { geography } \\
\text { 5 Items } \mid \alpha=.83\end{array}$ & 2.64 & 0.78 & 2.58 & 0.75 & 0.75 & n.s. & \\
\hline
\end{tabular}

In the self-related student characteristics (see table 2), significantly more positive values are shown in all three areas in relation to the GeoBox than for the previous geography lessons (medium effect size).

Table 2

Self-Related Student Characteristics in Comparison and Teaching with the Geobox, $N=43$

\begin{tabular}{|l|l|l|l|l|l|l|l|}
\hline & mean $_{\text {pre }}$ & $\boldsymbol{S D}_{\text {pre }}$ & $\boldsymbol{m e a n}_{\text {post }}$ & $\boldsymbol{S D _ { \text { post } }}$ & $\boldsymbol{t}(42)$ & $\boldsymbol{p}$ & $\boldsymbol{d}$ \\
\hline $\begin{array}{l}\text { topic-specific self- } \\
\text { efficacy } \\
4 \text { Items } \mid \alpha=.82\end{array}$ & 2.92 & 0.57 & 3.23 & 0.62 & 4.06 & $<.001$ & 0.62 \\
\hline $\begin{array}{l}\text { perceived } \\
\text { competence } \\
\text { 4 Items | } \alpha=.82\end{array}$ & 2.97 & 0.52 & 3.25 & 0.61 & 3.30 & $=.002$ & 0.50 \\
\hline $\begin{array}{l}\text { self-concept in } \\
\text { geography } \\
\text { 7 Items | } \alpha=.83\end{array}$ & 3.02 & 0.70 & 3.22 & 0.56 & 3.56 & $=.001$ & 0.54 \\
\hline
\end{tabular}

In particular, the "topic-specific self-efficacy" and the "perceived competence" related to the concrete teaching situations are thus evaluated more positively with regard to the GeoBox. Even the more enduring "self-concept in geography"changes slightly into the positive. It should also be taken into account that all three values were also already above the mean value of the scale of 2.5 , i.e. in the positive range, with regard to the normal geography lessons.

The process features practical activity, cognitive activating students' experiments and student-generated explanations show everywhere significantly more positive values in relation to the GeoBoxes (see table 3). In this area, however, it is not so much the comparison between normal lessons and GeoBox lessons that is of interest, but rather the GeoBox lessons themselves. 
Schubert, J. C. (2021). Developing geographic skills through experiments:implementing.....

Table 3

Student perceptions of process features of previous instruction compared to GeoBoxes, $N=43$

\begin{tabular}{|l|l|l|l|l|l|l|l|}
\hline & mean $_{\text {pre }}$ & $\boldsymbol{S D}_{\text {pre }}$ & mean $_{\text {post }}$ & $\boldsymbol{S D}_{\text {post }}$ & $\boldsymbol{t}(42)$ & $\boldsymbol{p}$ & $\boldsymbol{d}$ \\
\hline $\begin{array}{l}\text { practical activity } \\
\text { 3 Items | } \alpha=.58\end{array}$ & 2.07 & 0.78 & 3.58 & 0.47 & 10.85 & $<.001$ & 1.66 \\
\hline $\begin{array}{l}\text { cognitive activating } \\
\text { students' } \\
\text { experiments } \\
\text { 5 Items | } \alpha=.73\end{array}$ & 2.45 & 0.75 & 3.11 & 0.57 & 5.21 & $<.001$ & 0.80 \\
$\begin{array}{l}\text { student-generated } \\
\text { explanations } \\
\text { 5 Items | } \alpha=.76\end{array}$ & 3.20 & 0.57 & 3.39 & 0.57 & 2.96 & $=.005$ & 0.45 \\
\hline
\end{tabular}

The practical activity is rated very high with a mean value of 3.58. On the one hand, this was to be expected, on the other hand, it indicates that students, despite numerous phases with demanding cognitive activation (and without practical activity), nevertheless associate the GeoBox work as a whole with high practical components.

The GeoBox lessons are also clearly evaluated positively with respect cognitive activating students' experiments. For example, students state that they have better understood content through the scientific work methods.

Also with regard to the possibilities to find explanations themselves, to be able to go wrong ways at first, etc., the students evaluate the work with the GeoBoxes clearly positively, whereby the very positive value already at $\mathrm{t} 1$ is noticeable here. Central aspects of the educational concept (minds-on and hands-on) of the GeoBox are thus confirmed and can be seen as validated from the students' perspective.

\section{Discussion and Conclusion}

Being able to experiment is an important geographic skill, which (in Germany), however, is only rarely used in the classroom. The development of GeoBoxes, which can be borrowed by teachers and used directly in class, should improve the frequency of use. At the same time, the quality of the use in class is to be promoted by didactically and methodically prepared material: especially the cognitive activation (minds-on) during experimentation is in the foreground of the developed GeoBoxes. The GeoBoxes, which were developed in an iterative process, are evaluated positively by teachers and students; the accompanying research shows in particular a higher situational interest in the GeoBoxes than in the previous lessons. At the same time, it is not possible to say exactly what triggers the comparatively high situational interest. It is known from other research that the topics soil and agriculture do not belong to the topics of interest (Hemmer \& Hemmer, 2017; Hemmer, Hemmer, Warnke, \& Zietzsch, 2019) from the students' point of view. At the same time, GeoBoxes fulfill a number of criteria that are theoretically and empirically suitable for promoting (situational) interest (Hidi \& Renninger, 2006; Palmer, 2009): For example, it is an instructional setting that deviates from regular instruction, graded assistance can be used to create a fit with the different learning 
prerequisites of the students, there is a basic research character to the instructional setting, and hands-on activities are integrated. The individual interest in experimentation is also high compared to other ways of working (Hemmer, 2010). Even if the relative importance of the criteria listed is unclear in this specific case, accompanying research shows: The GeoBoxes are suitable for stimulating interest despite the less interesting topic of soil and agriculture to which they refer. This is an important, confirming finding, which at the same time can help in the communication with the teachers to prove the suitability of the GeoBoxes in a databased way.

In addition, teaching with the GeoBoxes is associated with positive, self-related experiences (self-efficacy and perceived competence are strongly higher, even the self-concept in geography as a persistent variable is slightly more positive).

Limitations of the accompanying research lie in particular in the still small sample size and the lack of a control group. Clear cause-effect statements are therefore not possible and the data refer to a very concrete teaching arrangement, which limits the transferability of the results. Nevertheless, the results can be interpreted as positive indications 1 ) that the use of scientific working methods within the GeoBox is indeed associated with positive motivational aspects and 2) that the integration of minds-on phases into hands-on work is viewed positively by students and does not appear to be counterproductive to motivation.

In the future, further GeoBoxes on other topics are to be developed, which also combine minds-on and hands-on activities in a meaningful way. The design cycles of the developed GeoBox and the evaluation strategies used in the form of teacher and student surveys have proven to be suitable for this purpose. At the same time, the research on the presented GeoBox, which so far mainly aimed at the improvement of the GeoBox in the sense of design-based-research, should be more strongly focused on effects of the GeoBox. In this context, not only motivational and self-related student characteristics, but also subject-related learning gains are to be considered. Methodically, a control group design will be used. In terms of content, the didactic principles hands-on and minds-on in experimentation and their relationship are of particular interest. Therefore, it is planned to modify the GeoBox and to use different variants (hands-on/minds-on) of the same GeoBox for comparison.

The development process with accompanying research can be used as inspiration for other geographical skills as well. The importance of systematically combining practical exercises and cognitive challenges has been confirmed with regard to experiments in geography lessons - this can be an important indication for the acquisition of other geographic skills as well. 


\section{References}

Adey, K., \& Biddulph, M. (2001). The Influence of Pupil Perceptions on Subject Choice at 14+ in Geography and History. Educational Studies, 27(4), 439-450. https://doi.org/10.1080/03055690120071894

Akuma, F. V., \& Callaghan, R. (2019). Characterising Extrinsic Challenges Linked to the Design and Implementation of Inquiry-Based Practical Work. Research in Science Education, 49(6), 1677-1706. https://doi.org/10.1007/s11165-017-9671-x

Bent, G. J., Bakx, A., \& Brok, P. den (2014). Pupils' Perceptions of Geography in Dutch Primary Schools: Goals, Outcomes, Classrooms Environment, and Teacher Knowledge and Performance. Journal of Geography, 113(1), 20-34. https://doi.org/10.1080 /00221341.2013.810299

Design-Based Research Collective (2013). Design-Based Research: An Emerging Paradigm for Educational Inquiry. Educational Researcher, 32(1), 5-8. https://doi.org/10.3102/0013189X032001005

Duit, R., Gropengießer, H., \& Stäudel, L. (2007). Naturwissenschaftliches Arbeiten: Eine Einführung [Working in the natural sciences: An Introduction]. In R. Duit, H. Gropengießer, \& L. Stäudel (Eds.), Naturwissenschaftliches Arbeiten: Unterricht und Material 5-10 (pp. 4-8). Seelze-Velber: Erhard Friedrich Verlag.

Duit, R., \& Tesch, M. (2006). Eigenständiges Experimentieren im naturwissenschaftlichen Unterricht-Theorie, empirische Forschungsergebnisse, Unterrichtspraxis [Independent experimentation in science education - theory, empirical research results, teaching practice]. Fachtagung „Selbständiges Lernen im Fachunterricht”, pp. $1-19$.

Edelson, D. C. (2002). Design Research: What We Learn When We Engage in Design. Journal of the Learning Sciences, 11(1), 105-121. https://doi.org/10.1207/ S15327809JLS1101_4

Feulner, B., Ohl, U., \& Hörmann, I. (2015). Design-Based Research - ein Ansatz empirischer Forschung und seine Potenziale für die Geographiedidaktik [Design-Based Research - an approach of empirical research and its potentials for geography didactics]. Zeitschrift Für Geographiedidaktik, 43(3), 205-232.

German Geographical Society (2014). Educational Standards in Geography Educational Standards in Geography for the Intermediate School Certificate: with sample assignments (3rd ed.). Bonn: German Geographical Society. Retrieved from https://geographie.de/wp-content/uploads/2016/06/geography_education.pdf

Hammann, M., Ganser, M., \& Haupt, M. (2007). Experimentieren können: Kompetenzentwicklungsmodelle und ihre Nutzung im Unterricht [Being able to experiment: Competence development models and their use in the classroom]. Geographie heute, 28(255-256), 88-91.

Hammann, M., Phan, T. T. H., Ehmer, M., \& Grimm, T. (2008). Assessing pupils' skills in experimentation. Journal of Biological Education, 42(2), 66-72. https://doi.org/10.1080/00219266.2008.9656113

Hemmer, I., \& Hemmer, M. (2010). Interesse von Schülerinnen und Schülern an einzelnen Themen, Regionen und Arbeitsweisen des Geographieunterrichts - ein Vergleich zweier empirischer Studien aus den Jahren 1995 und 2005 [Students' interest in individual topics, regions, and ways of working in geography classes - a comparison of two empirical studies conducted in 1995 and 2005]. In I. Hemmer \& M. Hemmer 
(Eds.), Schülerinteresse an Themen, Regionen und Arbeitsweisen des Geographieunterrichts. Ergebnisse der empirischen Forschung und deren Konsequenzen für die Unterrichtspraxis (pp. 65-145). Weingarten: Selbstverlag des Hochschulverbandes für Geographie und ihre Didaktik e.V. (HGD).

Hemmer, I., \& Hemmer, M. (2017). Teachers' Interests in Geography Topics and Regions How they Differ from Students' Interests? Empirical Findings. Review of International Geographical Education Online, 7(1). Retrieved from http://www.rigeo.org/vol7no1/Number1Spring/RIGEO-V7-N1-1.pdf

Hemmer, I., Hemmer, M., Warnke, M., \& Zietzsch, J. P. (2019). Welche Themen interessieren bayerische Schülerinnen und Schüler im Geographieunterricht? Ausgewählte Ergebnisse einer schulartübergreifenden empirischen Untersuchung in der Sekundarstufe I. [What topics interest Bavarian students in geography classes? Selected Results of an Empirical Investigation in Secondary Level I Across Schools.] Der Bayerische Schulgeograph, 41(85), 37-45.

Hidi, S., \& Renninger, K. A. (2006). The Four-Phase Model of Interest Development. Educational Psychologist, 41(2), 111-127. https://doi.org/10.1207/ s15326985ep4102_4

Höhnle, S., \& Schubert, J. C. (2016). Hindernisse für den Einsatz naturwissenschaftlicher Arbeitsweisen im Geographieunterricht aus Studierendenperspektive [Barriers to the use of science work practices in geography classrooms from a university student perspective]. Ausgewählte Ergebnisse einer empirischen Studie mit Lehramtsstudierenden. GW-Unterricht: Eine Zeitschrift Des "Forums GW - Verein Für Geographie Und Wirtschaftserziehung, 153-161.

Institut für Schulqualität und Bildungsforschung München (2020). LehrplanPLUS: Geographie (Gymnasium). Retrieved from https://www.lehrplanplus.bayern.de/schulart/gymnasium/fach/geographie/inhalt /fachlehrplaene

Kauertz, A., Kleickmann, T., Ewerhardy, A., Fricke, K., Lange, K., Ohle, A., .. Möller, K. (2013). Dokumentation der Erhebungsinstrumente im Projekt PLUS [Documentation of the survey instruments in the PLUS project]. Retrieved from https://duepublico2.unidue.de/receive/duepublico_mods_00035341

Klahr, D., \& Dunbar, K. (1988). Dual Space Search During Scientific Reasoning. Cognitive Science, 12(1), 1-48. https://doi.org/10.1207/s15516709cog1201_1

Mattissek, A., Pfaffenbach, C., \& Reuber, P. (2013). Methoden der empirischen Humangeographie [Methods of empirical human geography]. Braunschweig: Westermann.

Miener, J. P., \& Köhler, K. (2013). Experimentelle Arbeitsweisen im Geographieunterricht: Vorstellungen von Geographielehrern zu Chancen und Barrieren [Experimental ways of working in the geography classroom: geography teachers' perceptions of opportunities and barriers]. (1. Aufl.). Saarbrücken: AV Akademikerverlag.

Möller, K. (2000). Verstehendes Lernen im Vorfeld der Naturwissenschaft? Forschung für den Sachunterricht. [Learning in advance of science? Research for general studies in primary schools]. Die Grundschulzeitschrift, 14(139), 54-57.

National Research Council (2012). Framework for $k$-12 science education - practices, crosscutting concepts, and Core Ideas. Washington, D.C.: National Academies Press. 
Otto, K.-H. (2009). Experimentieren als Arbeitsweise im Geographieunterricht. [Experimentation as a way of working in geography lessons]. Geographie Und Schule. (180), 4-15.

Palmer, D. H. (2009). Student interest generated during an inquiry skills lesson. Journal of Research in Science Teaching, 46(2), 147-165. https://doi.org/10.1002/tea.20263

Parchmann, I. [Ilka], \& Prenzel, M. (2003). Kompetenz entwickeln. Vom naturwissenschaftlichen Arbeiten zum naturwissenschaftlichen Denken [Developing competence. From scientific work to scientific thinking]. Naturwissenschaften im Unterricht. Chemie, 14(76-77), 15-19.

Pfeffer, K.-H. (2006). Arbeitsmethoden der Physischen Geographie. Geowissen kompakt [Working methods of physical geography. Geoknowledge compact]. Darmstadt: WBG.

Roberts, M. (2010). Geographical enquiry. Teaching Geography, 35(1), 6-9.

Schubert, J. C. (2016). Kognitiv aktivierend und eigenständig Experimentieren: Schüler erforschen das Wasserhaltevermögen von Böden [Cognitively activating and independent experimentation: Students explore the water-holding capacity of soils]. Geographie Aktuell \& Schule, 38, 24-34.

Tesch, M., \& Duit, R. (2004). Experimentieren im Physikunterricht - Ergebnisse einer Videostudie [Experimentation in physics lessons - results of a video study]. Zeitschrift für Didaktik der Naturwissenschaften, 10, 51-69. Retrieved from ftp://ftp.rz.unikiel.de/pub/ipn/zfdn/2004/3.Tesch_Duit_051-070.pdf

Wilhelm, T., \& Hopf, M. (2014). Design-Forschung [Design-Research]. In D. Krüger, I. Parchmann, \& H. Schecker (Eds.), Methoden in der naturwissenschaftsdidaktischen Forschung (pp. 31-42). Berlin, Heidelberg: Springer Berlin Heidelberg; Imprint: Springer Spektrum. https://doi.org/10.1007/978-3-642-37827-0_3

\section{Biographical Statement}

Jan Christoph SCHUBERT is a Full Professor at the Chair for Geography Education, Friedrich-Alexander-Universität Erlangen-Nürnberg. His research interests are in the area of geography education and focus on teacher profession, students' perceptions and interests, and Scientific Literacy in geography education. 